\title{
O SUBSYDIARNOŚCI RACZEJ NIEKONWENCJONALNIE
}

\section{SUBSIDIARITY. SOME RATHER NON-CONVENTIONAL REMARKS}

\section{Streszczenie}

Znaczenie nadawane w literaturze przedmiotu pojęciu subsydiarności jest węższe niż dają ku temu podstawy papieskie encykliki, w szczególności Piusa XI Quadragesimo Anno. Jej pojemność uzasadnia traktowanie jej nie jako zasady, lecz jako idei scalającej sytuacje społeczne i organizacyjne rozwiązania przywiązujące szczególną wagę do zachowania autonomii i podmiotowości. Tak rozumiana łączy dotychczas dzielone. I w tym widzę jej poznawczą i praktyczną użyteczność.

Słowa kluczowe: autonomia; centralizacja vs decentralizacja zarządzania; demokracja; godność jednostki ludzkiej; subsydiarność; samorząd terytorialny.

\begin{abstract}
The importance given to the concept of subsidiarity in the scientific literature is narrower than bases given in papal encyclicals, in particular Pius XI Quadragesimo Anno. Its capacity justifies the treating of it not as a principle, but as an idea merging social situations and organizational solutions which attach particular importance to preserve the autonomy and subjectivity. Understood in this way, it combines what was previously shared. And in this I see her cognitive and practical usability.
\end{abstract}

Keywords: autonomy; centralization vs decentralization in management; democracy; human dignity; subsidiarity; territorial self-government. 
Piszący o subsydiarności - zwłaszcza, gdy tymi piszącymi są prawnicy i politolodzy - zwykle uważają ją za zasadę. Nie sądzę, aby taka zawężająca to pojęcie kategoryzacja była trafna. I niczego pod tym względem nie zmienia mówienie o niej jako o zasadzie (pomocniczości) w preambule polskiej Konstytucji z 1997 roku czy innych oficjalnych, wysokiej rangi dokumentach. Nazwanie jej w Konstytucji zasadą nie przesądza o trafności czy nietrafności takiej jej kategoryzacji, ono przesądza o nadaniu jej normatywnego charakteru. Taki jej charakter nie wyklucza możliwości wykorzystywania jej przy opisie tego, co jest, opisie zastanego. A tutaj interesuje mnie taki właśnie opis, obce mi jest formułowanie zaleceń, formułowanie propozycji rozwiązań.

Czym jest zasada? Jest ogólnym wskazaniem zalecającym taki właśnie a nie inny wybór rozwiązania pojawiającego się w danych okolicznościach problemu. Świadomość, że w swoich zachowaniach kierują się nimi i inni ułatwia społeczne funkcjonowanie ułatwiając przewidywanie zachowania tych innych. Zasady pomagają w działaniu, wyznaczają kierunek lub sposób działania, ograniczają możliwości dokonywania poszczególnych, cząstkowych wyborów, których ewentualne nierespektowanie jeśli ma miejsce powinno być szczególnymi okolicznościami usprawiedliwione ${ }^{1}$. To instrumenty, których poszczególni z nas podobnie - w dobrej lub złej sprawie - powinniśmy użyć.

Bardziej ogólne od zasad są idee, nie tyle wskazujące przyszłe uznawane za pożądane do osiągnięcia cele, co eksponujące wagę problemów i możliwość sięgania do różnych możliwych podejść przy ich rozwiązywaniu². I taką właśnie ideą jest subsydiarność. Taki epistemologiczny status przyznaje jej Chantal Millon-Delsol, choć o tyle różnie od tutaj przyjmowanego, bo nie teleologicznie, lecz w odniesieniu do tłumaczenia zaszłości ${ }^{3}$ Jej ogólność, złożoność i wieloznaczność znajduje wyraz w sięganiu do niej nie tyle w mniej co bardziej różniących się między sobą kontekstach i sprawia, że w teorii dobrze byłoby te różne interpretacje i odwołania się staranniej identyfikować i interpretować. Uchwycić różne wiązane z subsydiarnością treści w zależności od tego gdzie, w jakich warunkach ${ }^{4}$ znajduje zastosowanie, a właściwiej byłoby

1 Por. L. Habuda, Jednolitość kierowania w literaturze organizacji i zarzadzania, „Prakseologia" 1975, nr 1 .

2 Zob. M. Ossowska, O dwóch rodzajach ocen, „Kwartalnik Filozoficzny” 1964, nr 2-4, s. 279 oraz J. Wróblewski, Zagadnienia teorii wyktadni prawa ludowego, Warszawa 1959, s. 53 i n.

3 Ch. Millon-Delsol, Zasada pomocniczości, Kraków 1995, s. 5 i n.

4 Tamże, s. 6 i n. 
chyba powiedzieć, gdzie odwoływanie się do niej jest wykorzystywane dla - mniej lub bardziej przekonującego - uzasadniania przyjmowanego ustrojowego (strukturalnego) rozwiązania.

Jest to idea, w której jako przewodni społeczny i polityczny motyw odnajduję - i to jest zasadniczy powód mojego nią zainteresowania - w postaci upodmiotowiania jednostek (osób), organizacji, mniejszych i większych społeczności, państw jako organizacji bardzo szczególnych, i nie tylko ze względu na aspirowanie zorganizowanych w nie zbiorowości do zachowania niezależności, wreszcie podmiotów działających w skali przekraczającej granice poszczególnych państw. Wszystkie przyjmowane w ich ramach rozwiązania mogą być traktowane jako jej istoty rozwinięcie, wyciągnięcie z niej wielorakich możliwych konsekwencji.

Upodmiotowienie egalitaryzując bardzo różne relacje społeczne i organizacyjne, w tym też z samej swej natury nieegalitarne relacje władzy - szczególnie gdy eksponowane w nim jest literalnie rozumiane pomaganie - raczej nie broni się aksjologicznie. Może być wykorzystane w złej sprawie, np. w imię wytłumaczenia i uzasadnienia władzy oligarchizacji. Jak choćby dzieje się to w Rosji Putina, w której relacje władzy opierają się na poparciu udzielanym sprawującym władzę przez niemających - jak to określa Garij Kasparow - gdzie pójść. „Określiłbym Putina mianem szefa szefów, cappo di tutti cappi. Świetnie gra rolę takiego, który równoważy interesy grup żyjących kosztem rosyjskiego budżetu. Te grupy ludzi niemające gdzie pójść po upadku Putina, będą ostro walczyć o zachowanie systemu. A co - dalej pyta G. Kasparow - utrzymuje Putina przy władzy w oczach opinii publicznej? To strach przed tym, co może się zdarzyć. To największy problem dla opozycji, gdyż obywatele mają w genach strach przed zmianami. Ludzie myślą, że władza może nie jest idealna, ale jeśli pchniemy rząd na skraj przepaści, to Bóg wie co może się zdarzyć"5.

Bodajże najczęstszy ze spotykanych sposobów opisywania subsydiarności to sprowadzanie jej do udzielania pomocy słabszym i mniejszym, „Wyższe szczeble organizacji społecznej i administracji są po to, żeby pomagać niższym...".6. A. Piasecki artykuł mający za przedmiot subsydiarność rozpoczyna od zdania: „W świetle zasady pomocniczości władza publiczna wyższego szczebla

5 System Putina. Garri Kasparow w rozmowie z autorem „, Tygodnika”, Jackiem Stawiskim, „Tygodnik Powszechny” z dn. 21.10.2012 r.

6 Społeczeństwo obywatelskie bez obywateli. Z prof. Andrzejem Sicińskim, socjologiem kultury o obrazie Polski w Europie, elitach i klikach politykierów rozmawia Mariusz Urbanek, „Odra” 2006, nr 1, s. 3. 
powinna wspierać niższe struktury organizacyjne w wypełnianiu ich zadań W tym kontekście samorząd województwa jest adresatem pomocy ze strony państwa i Unii, ale i sam stanowi podmiot realizujący zasadę subsydiarności na rzecz powiatów i gmin"?.

Takie też - eksponujące pomaganie mniejszym i słabszym - jej rozumienie odnajdujemy w kontekście, w jakim pisze o subsydiarności M. Kulesza, jeden $\mathrm{z}$ trzech głównych współtwórców ustroju polskiego terytorialnego samorzą$\mathrm{du}^{8}$ : „Mówimy (...), że zasada ta powinna być podstawą pomocy jednostkom, rodzinom, mniejszościom narodowym itp. Zastanawiałem się, słuchając tych słów, nad pewnym przypadkiem, jaki miał miejsce w Polsce pod koniec 1995 r. Istnieje mianowicie w województwie sieradzkim pewna gmina, która z przyczyn od siebie niezależnych po prostu zbankrutowała. I oto «wśród serdecznych przyjaciół psy zająca zjadły». Mimo konstytucji, mimo sejmików, mimo rządu, mimo Sejmu i Senatu okazało się, że zasada subsydiarności nie działa".

Ze swej strony poważnie wątpię czy akurat w tym przypadku o subsydiarność naprawdę chodzi i czy o nią chodzić powinno. Choć nie zaprzeczam, że, jak się bardzo chce, to w takich przypadkach związków z nią doszukać się można. Ale tak rozumując odpowiedzialnością za nieudolność i opieszałość mniejszych, słabszych i biedniejszych zawsze można by przerzucić na większych, silniejszych i zasobniejszych.

Jeśli miałbym szukać uzasadnienia dla udzielenia pomocy takiej, jak przywołana przez M. Kuleszę, gminie to odwoływałbym się nie do subsydiarności, lecz do wzywającej do udziału w noszeniu ciężarów bliźnich społecznej solidarności ${ }^{10}$ oraz chrześcijańskiej caritas $^{11}$. I jeszcze do tego, zanim odwołałbym się do nich - pozostając pod tym względem w pełnej zgodzie z klasycznymi ich ujęciami - starałbym się rozważyć czy udzielana tak wspieranej gminie pomoc

7 A. Piasecki, Pomocniczość samorzadowego województwa. Teoria i praktyka, [w:] A. Pawłowska, S. Gawłowska (red.), Zasada pomocniczości. Wymiar europejski, narodowy, regionalny i lokalny, Wydawnictwo Uniwersytetu Rzeszowskiego, Rzeszów 2011, s. 210.

8 Por. L. Habuda, Polska reforma terytorialnego samorzadu. Osobisty ślad odciśnięty na niej przez jej trzech współautorów, „Atheneaum. Polskie Studia Politologiczne” 2015, nr 47, s. 133-146.

$9 \quad$ M. Kulesza, Zasada subsydiarności jako klucz do reform ustroju administracyjnego państw Europy Środkowej i Wschodniej (na przykładzie Polski), [w:] D. Milczarek (red.), Subsydiarność, Warszawa 1998, s. 119.

10 K. Frysztacki, Solidarność, [w:] M. Bogunia-Borowska (red.), Fundamenty dobrego społeczeństwa. Wartości, Kraków 2015, s. 212-231.

11 A. Jasińska-Kania, Miłość, [w:] Fundamenty..., s. 83-97. 
naprawdę dobrze się jej przysłuży. Nie każda pomoc pomaga, pomoc źle adresowana, udzielana zbyt pochopnie korzystającym z niej beneficjentom może być przysłowiową niedźwiedzią przysługą. Komu służy sztuczne przedłużanie nędznego, niedającego się naprawić, obciążającego innych związanymi z tym kosztami, organizacyjnego trwania? Co to za pomoc, która, nijak nie służąc poprawie tylko przedłuża „organizacyjne męki”12.

Ratowanie istnienia gminy czy jakiejkolwiek innej organizacji ${ }^{13}$ to nie to samo co ratowanie życia ludzkiego czy ludzkiej godności. Szybsze zakończenie nieudanego organizacyjnego przedsięwzięcia to jednocześnie przyspieszenie momentu podjęcia przedsięwzięcia nowego, korygującego. Nie bez znaczenia są także koszty takiej pomocy. Dobrze by było, aby ich ponoszenie broniło się, aby dało się swą przewidywaną skutecznością przekonująco uzasadnić.

Sądzę, iż takie rozumowanie da się pogodzić ze społeczną wrażliwością. Skojarzenie z nią stąd, że w nauce społecznej Kościoła pojawiła się pomocniczość sprowadzana do pomagania w kontekście szczególnie nabrzmiałej kwestii robotniczej. To ona stała się przedmiotem encykliki Rerum novarum z 1891 roku. Encykliki wydanej w warunkach nasilającej się walki klasowej, przybierających na sile w środowiskach robotniczych ruchów socjalistycznych i postępującego przejmowania przez partie socjalistyczne, w tym marksistowskie kontroli nad nimi. W drugim zdaniu tej encykliki czytamy: „A nowe postępy w przemyśle i nowe metody produkcji, zmiana stosunków miedzy przedsiębiorcami a pracownikami najemnymi, napływ bogactw do rąk niewielu przy równoczesnym zubożeniu mas, wzrost zaufania samych pracowników we własne siły i łączności między nimi, nade wszystko zaś pogorszenie się obyczajów, sprawiły, że walka (społeczna) zawrzała"14. Z kolei sformułowane w niej zalecenia koncentrowały się na zadaniach państwa: „Państwo winno otoczyć swoją opieką różne interesy robotnika...”; „Stąd wynika konieczność spoczynku i wstrzymania pracy w dni świąteczne...”; „Jeśli zaś chodzi o dobra cielesne i zewnętrzne, to naprzód winno państwo wyzwolić pracowników z niewoli ludzi chciwych, którzy dla celów zysku bez miary nadużywają osób, jak rzeczy martwych...”; „Odnośnie zaś do młodzieży pilnie baczyć należy, by nie pierwej szła do fabryk, aż z upływem lat osiągnie wystarczający rozwój

12 Mówię o „mękach organizacyjnych” dla uniknięcia ewentualnego zaliczenia mnie do zwolenników eutanazji, pod którą trudniej byłoby mi się podpisać.

13 Może z wyjątkiem, mającego prawo do swego rodzaju nieśmiertelności, państwa.

14 Leon XIII, O kwestii robotniczej (Rerum novarum), [w:] Społeczne nauczanie Kościoła, „Znaki” 1982, nr 332-334, s. 644. 
cielesny, umysłowy i duchowy...”; „Chociaż więc pracownik i pracodawca wolną z sobą zawrą umowę, a w szczególności ugodzą się co do wysokości płacy, mimo to jednak ponad ich wolą zawsze pozostanie do spełnienia prawo sprawiedliwości naturalnej, ważniejsze i dawniejsze od wolnej woli układających się stron..."15.

Dostrzeżone w niej zostały stowarzyszenia, a wśród nich przede wszystkim związki zawodowe. „Doświadczenie codzienne uczy człowieka, że siły ma słabe; ono go też skłania i wzywa do starania się o pomoc drugich"16.

Octogessimo anno właściwej Rerum novarum ostrożności wobec pozostających państwu do spełnienia zadań już nie miało. Idzie w swej refleksji mającej za przedmiot pozostające państwu do spełnienia zadania na tyle daleko, że formułuje pod jego adresem ustrojową w swej naturze zasadę subsydiarności.

Czymże więc jest w tej encyklice interesująca nas tutaj subsydiarność? Świadomie powtarzam się: to upodmiotowienie jednostek, społeczności i społeczeństwa. Także poprzez uzupełnienie demokratycznych prawnych instytucji o to, co P. Rosanvallon nazywa kontrdemokracją. „Kontrdemokracja nie jest tu (...) - pisze cytowany autor - przeciwieństwem demokracji. To raczej forma demokracji, która przeciwstawia się innej formie, demokracja władz pośrednich, rozsianych po całym ciele społecznym, demokracja zorganizowanej nieufności, pod adresem demokracji legitymizowanej procesem wyborczym (podkr. L. H.). Ta kontrdemokracja współtworzy wraz z legalnymi instytucjami demokratycznymi pewien system" ${ }^{17}$. Jest demokracji, przybierającej postać sformalizowanych, strukturalnych rozwiązań, wzbogaceniem, uzupełnieniem o dodanie do rozwiązań formalnych wzmacniających je podstaw społecznych, ekonomicznych i kulturowych.

Zgodnie z Piusa XI encykliką Quadragesimo anno z 1931 roku, w której termin subsydiarność pojawił się po raz pierwszy ${ }^{18}$, polega ona na tym, że to „co jednostka z własnej inicjatywy i własnymi siłami może zdziałać, tego jej nie wolno wydzierać na rzecz społeczeństwa; podobnie niesprawiedliwością, szkodą społeczną i zakłóceniem ustroju jest zabieranie mniejszym i niższym

\footnotetext{
Tamże, s. 666-669.

Tamże, s. 671.

P. Rosanvallon, Kontrdemokracja. Polityka w dobie nieufności, Wrocław 2011, s. 11.

Shoć samej idei bez trudu można doszukać się w poprzedzającej tę encyklikę myśli społecznej, cofając się wstecz od Rerum novarum do G.W. Hegla, A. de Tocqueville'a, A.F. Modrzewskiego, Marsyliusza z Padwy, Tomasza z Akwinu, na samym Arystotelesie kończąc. Por. Ch. Mellon-Delsol, Zasada pomocniczości..., passim.
} 
społecznościom tych zadań, które mogą spełnić i przekazywanie ich społecznościom większym i wyższym (podkr. L. H.). Każda akcja społeczna ze swego celu i ze swej natury ma charakter pomocniczy; winna pomagać członkom organizmu społecznego, a nie niszczyć ich lub wchłaniać"19. I do tego fragmentu tego, co miał Pius XI do powiedzenia o subsydiarności najczęściej się nawiązuje. Generalnie wspierając nim prodecentralizacyjne orientacje.

Na tym encyklikowa subsydiarność się jednak nie kończy. Jej rozwinięciem są oczekiwania formułowane pod adresem większych, silniejszych bądź wyżej w hierarchii usytuowanych, włącznie z państwem i jego centralnymi władzami. „Z tego względu władza państwowa (centralne organy i centralny aparat władzy państwowej - dopisek L. H.) powinna niższym społecznościom zostawić do wypełnienia mniej ważne zadania i obowiązki, które by ją (chodzi oczywiście o władzę państwa jako politycznego i prawnego podmiotu - dopisek L. H.) zresztą zbyt rozpraszały. To zaś pozwoli jej na swobodniejsze, bardziej stanowcze i skuteczniejsze wykonywanie tych obowiązków, które do niej należą i które tylko ona może wykonać, mianowicie: kierownictwo, kontrola, nacisk, karanie nadużyć, w zależności od tego, co się wysuwa w danej chwili i czego żąda potrzeba (podkr. L. H.). Sprawujący władzę winni być przekonani, że im doskonalej na podstawie tej zasady «pomocniczości» przeprowadzony będzie stopniowy ustrój (raczej powiedziałbym: podział kompetencji (zadań i uprawnień) - dopisek L. H.) między poszczególnymi społecznościami, tym większy będzie autorytet społeczny i energia społeczna, tym też szczęśliwszym i pomyślniejszym będzie stan spraw państwa" ${ }^{20}$, tym racjonalniej zbudowana jego struktura. W strukturach konstruowanych - a tak rzecz się ma w przypadku organów i aparatu władzy państwowej - pojawia się miejsce na racjonalne rozmieszczenie w nich kompetencji (zadań i uprawnień). Zawsze jednak z uwzględnieniem społecznych reakcji na nie. „Jakby mnie pan pytał - odpowiada D. Tusk na wynikające z kontekstu rozmowy (jednak) pytanie - czy nie byłoby fajnie, żeby Europa zjednoczyła się naprawdę i miała jeden wspólny interes i zarząd, żadnych granic miedzy krajami i ludźmi, to powiedziałbym, że to absolutnie piękne marzenie. Jednak nie ma większych kłopotów w polityce jak te, które rodzą się z pięknych marzeń. A praktyczny wymiar tego jest bardzo prosty: kto miałby rządzić taką Europą, w której stolice narodowe tracą władzę? No kto? Komisja? Wyobraża pan sobie ten

19 Pius XI, Quadragesimo anno, [w:] Nauka społeczna Kościoła, „Znak” 1984, nr 7-9 (332334), s. 708.

20 Tamże, s. 708. 
entuzjazm dzisiaj w Europie, gdyby ludzie się nagle dowiedzieli, że od jutra we wszystkim podlegają Komisji Europejskiej"21. Do takiego scentralizowanego rządzenia społeczeństwa Europy jeszcze nie dojrzały. Rozwiązania ustrojowe zawsze funkcjonują nie w pustce, lecz w jakimś społecznym kontekście.

Bez odniesień do subsydiarności wiele napisano na ten właśnie temat w nawiązującej do prakseologii polskiej nauce administracji (o administrowaniu ${ }^{22}$. Zauważmy, że takich odniesień do subsydiarności nie było i w zachodniej nauce organizacji i zarządzania. I w zasadzie nie ma ich i dzisiaj. Tłumaczyłbym ten stan ich brakiem szczerego zainteresowania organizacyjną demokracją i organizacyjną stroną demokracji. Ale też ich związek z demokracją daje się sprowadzić przede wszystkim do zwiększania poprzez decentralizację władzy i rządzenia/zarządzania ilości wejść, poprzez które poddani państwowej władzy mogą na tę władzę oddziaływać i w ten sposób uczestniczyć w niej²3.

To samo - oczywiście jeśli chodzi o zainteresowanie nimi - da się powiedzieć o pozycji jednostki (prawach człowieka), stowarzyszeniach (organizacjach pozarządowych), sprawiedliwości społecznej (płace, dochody, zabezpieczenie społeczne) czy granicach ingerencji państwa (liberalizm vs etatyzm). To nie są problemy, których podjęcie jest następstwem wywodzenia ich z subsydiarności. One były i są podejmowane niezależnie od niej. Czy skojarzenie ich w bardziej zbiorczej kategorii subsydiarności wniosło wkład w refleksję i praktykę? Nie odpowiadam na to pytanie. Ograniczę się do zauważenia - co do tego nie mam wątpliwości - że ujawniło społeczną wrażliwość Kościoła, wyprowadziło ją poza tradycyjną dobroczynność i udzielanie pomocy najbiedniejszym i najbardziej bezradnym. To chyba bardziej zmiana w samym Kościele, w jego społecznym nauczaniu, niż w jego społecznym i politycznym otoczeniu.

Subsydiarność to konstrukcja bardzo pojemna. Mieści się w niej nie tylko postulat pozostawiania mniejszym, począwszy od - stanowiącej fundament całej konstrukcji - indywidualnej osoby ludzkiej, maksimum możliwej samodzielności, ale i oczekiwanie stosownej aktywności po stronie - bardzo

21 Wszystkie winy Tuska. Rozmowa z Donaldem Tuskiem, przewodniczacym Rady Europejskiej o przyszłości Unii, polskiej polityki i swoim w niej udziale. Rozmawiał Jerzy Baczyń$s k i$, „Polityka” z dn. 13.07.2016 r.

22 Najwięcej miał w tej materii do powiedzenia S. Kowalewski w Nauce o administrowaniu, Warszawa 1976, s. 128-171.

23 S. Verba, N.H. Nie, Jae-on Kim, Participation and Political Equality. A Seven Nation Comparison, Chicago and London 1987, s. 46 i n. 
różnie konstruowanych organizacji społecznych (non-governmental organizations) - oraz podmiotów większych, łącznie z największym w postaci państwa i sprawowanej w jego imieniu państwowej władzy. Tę wymaganą przez subsydiarność konieczność wyważania aktywności różnych podmiotów eksponuje również Ch. Millon-Delsol: ,zasada subsydiarności zakłada istnienie organizacji społeczno-politycznej, w której kompetencje lub zdolność do działania przypisane są w pierwszym rzędzie aktorom społecznym. W przypadku, gdy działania tych aktorów okażą się niewystarczające, w drugiej kolejności owe kompetencje i zdolności przechodzą na bardziej złożone instancje wyższe, by wreszcie - jeżeli żadna inna instancja społeczna nie okaże się skuteczna przejść w gestię państwa"24.

W ujęciu tym odnajduję wyraźne uporządkowanie poziomów społecznej aktywności: pierwszego, indywidualnego (jednostkowego), liberalnego, bliskiego S. Ossowskiego kategorii pierwszego ładu społecznego, nijak niekoordynowanej aktywności osób chodzących własnymi ścieżkami ${ }^{25}$; drugiego, też naturalnego, wielopodmiotowego niekonstruowanego, społecznego, koordynującego swe poczynania poprzez zinternalizowane normy i wartości, po części przypominającego P. Rosanvallona kontrdemokrację; trzeciego, organizującego podmioty pierwszego i drugiego, złożonego z celowo zorganizowanych instytucji (non-governmental organizations); oraz czwartego, tworzonego przez w sensie weberowskim zhierarchizowane organy i aparat władzy państwowej, mniej lub bardziej (ale jednak) podporządkowującego sobie wcześniej wyróżnione i piątego (to już moje rozwinięcie koncepcji S. Ossowskiego), ponadpaństwowego, związku państw w rodzaju Unii Europejskiej. Obszary (poziomy) indywidualny i państwowy wyróżniają się spośród pozostałych.

Szczególną pozycję ładu pierwszego tłumaczy niezbywalna godność osoby ludzkiej. W nauce społecznej Kościoła znajduje ona swoje filozoficzne uzasadnienie w chrześcijańskim personalizmie. W uznaniu, że „Człowiek jest osobą, to znaczy między innymi naturą zindywidualizowaną jednocześnie kimś innym i żadna, będąc w najbardziej pierwotnym znaczeniu sobą, nie może stać się kimś innym. Pomiędzy moim Ja i twoim Ja nie ma drabiny, jest przerwa"26.

24 Ch. Millon-Delsol, Zasada subsydiarności-założenia, historia, problemy współczesne, [w:] D. Milczarek (red.), Subsydiarność, Warszawa 1998, s. 31.

25 S. Ossowski, Koncepcje ładu społecznego i typy przewidywań, [w:] tegoż, O osobliwościach nauk społecznych, Warszawa 1962, s. 114.

26 J. Tischner, Z problematyki wychowania chrześcijańskiego, [w:] tegoż, Świat ludzkiej nadziei, Kraków 1992, s. 30. 
Jako osoby w swej godności, przysługującej każdemu z nas z racji naszego człowieczeństwa, jesteśmy równi. Dzisiaj do tego uzasadnienia wyróżnionej pozycji jednostki ludzkiej można by dodać i zwykle dodaje się jej ,prawo do posiadania praw", kreację jej upodmiotowienia ${ }^{27}$, tegoż upodmiotowienia uspołecznienie, rozciągnięcie go na funkcje pełnione w zbiorowości. To szczególne usytuowanie, uprzywilejowujące pozycję jednostki ludzkiej w subsydiarności, uzasadnia wywodzenie z niej wszystkich praw i obowiązków społeczeństwa i państwa ${ }^{28}$. Ale też nie zdejmuje z jednostek ograniczeń wynikających z pełnienia różnych ról, przynależności do różnych organizacji, różnych społeczności, społeczeństwa i wreszcie państwa i tego co ponad państwem.

Z kolei szczególność pozycji zajmowanej przez państwo wynika co najmniej z dwóch powodów. Po pierwsze, stąd że, gdy demokratyczne, jest organizacją zbiorowości będącej suwerenem. Dzisiaj, w warunkach globalizacji i pojawienia się związku państw, suwerenność ta mocno odbiega od tradycyjnych jej wyobrażeń. Jest, aby być w możliwie znaczącym zakresie zachowana, w pewnym sensie podzielona - zyskiwana w zespołowej grze, w dogadywaniu się. Po drugie, stąd że dla każdej politycznej - w państwo zorganizowanej zbiorowości najbardziej fundamentalną wartością jest państwa trwanie i dziś, i w przyszłości. Nawiązując do tego, co o wartości państwa mieli do powiedzenia tacy autorzy jak Platon, św. Augustyn i Machiavelli, Ch. Mellon-Delsol bezpośrednio odwołując się do Cycerona stwierdza: „Wszelki (...) upadek całkowity państwa nie jest naturalny, tak jak naturalna jest śmierć człowieka, bo śmierć dla człowieka jest i zgładzone, to zdaje się wtedy (...) jak gdyby świat cały zapadł się i zginął"29.

Państwo powinno być tak urządzone, aby było wieczne. A tę szansę traci, gdy za sprawą albo słabości władzy przestaje być faktycznie rządne, albo za sprawą jednostronnego uzależnienia od innych państw traci niezależność, zdolność do samostanowienia o sobie. Inaczej jak od poszczególnych śmiertelnych osób od poszczególnych państw oczekuje się nieśmiertelności. W każdym razie długiego, możliwie najdłuższego, trwania, tak jak je rozumiał Braudel i francuscy annaliści.

27 Por. A. Touraine, Myśleć inaczej, Warszawa 2011, s. 19.

28 E. Popławska, Wplyw zasady subsydiarności na przemiany ustrojowe w Polsce, [w:] D. Milczarek (red.), Subsydiarność, Warszawa 1998, s. 139.

29 Ch. Delsol, Czym jest czlowiek? Kurs antropologii dla niewtajemniczonych, Kraków 2011, s. 62. 
Aktywność oczekiwana w ramach encyklikowej subsydiarności szanując indywidualizm powinna wielorako upodmiotowiać, uspołeczniać i jednocześnie organizacyjnie integrować. Stwarzać warunki dla wielorakich identyfikacji. Jako taka jest ideologicznie użytecznym konceptem dla wywodzenia z niego aksjologicznego uzasadnienia dla demokratyzujących autokratyczne systemy polityczne reform. I tak też została w Polsce po 1989 roku wykorzystana. To swego rodzaju mit założycielski polskiej ustrojowej transformacji.

Chodzi w niej nie tylko - choć to szczególnie ważne - o stworzenie możliwości wykazania się samodzielną aktywnością mniejszym i słabszym, lecz o znacznie więcej, a mianowicie o taki podział zadań w strukturze społeczeństwa, społeczności, poszczególnych organizacji, wreszcie państwa, państwowego aparatu i systemu politycznego, w którym jest miejsce na aktywność zarówno mniejszych i słabszych jak i większych i silniejszych. W podziale tym jest miejsce nie tylko dla jednostek i mniej lub bardziej liczebnych społeczności, ale i dla celowych organizacji oraz państwa i jego aparatu władzy. Problemem pozostaje, jakie są to te miejsca, pozycje i jakie zadania. Jako że niestanowiące zasady, lecz ideę z konieczności różne.

Nie ze wszystkimi propozycjami ich definiowania jestem w stanie się zgodzić. Przykładowo, generalnie zgadzam się z J. Regulskim gdy pisze: „...gmina ma się zajmować tym, czego pojedynczy człowiek wraz z rodziną wykonać nie może. $\mathrm{Z}$ kolei powiat powinien być traktowany jako pomocniczy w stosunku do gminy, a województwo do powiatu. Ta sama zasada odnosi się również do państwa i jego rządu. Państwo ma być pomocnicze w stosunku do wszystkich instytucji i organizacji działających w jego ramach i służących obywatelom"30. Ale już zupełnie nie zgadzam z J. Regulskiego utożsamianiem pomocniczości z odrzucaniem wszelkich zależności hierarchicznych: „Zasada pomocniczości odrzuca zależność hierarchiczną ${ }^{31}$. Jak można bowiem wymagać, aby jednostka «niższa» była podporządkowana «wyższej», jeśli ta ostatnia ma być jedynie pomocnicza w stosunku do tej «niższej»" ${ }^{32}$. Zaprzeczanie istnieniu hierarchii to zamykanie oczu na oczywiste powszechnie występujące w przyrodzie i życiu społecznym fakty. Hierarchia była jest i będzie, jest wszędzie,

30 J. Regulski, Samorzadna Polska, Warszawa 2005, s. 21.

31 Jak z kontekstu wynika utożsamianą z weberowską hierarchią wertykalną, zależnościami charakterystycznymi dla relacji władzy. Co nie jest tym samym co PRL-owskie tzw. hierarchiczne (personalne i służbowe) podporządkowanie.

32 J. Regulski, Samorządna Polska.., s. 21. 
w tym i w świecie zwierząt ${ }^{33}$, a już zupełnie nie sposób wyobrazić sobie bez niej relacji władzy. Mylę, iż tymi, którzy najczęściej mówią o jej odejściu do lamusa historii są usytuowani na jej szczytach lub na ich usługach pozostający.

Nadto pojawia się problem języka, znaczenia przypisywanego użytym w cytowanej wypowiedzi dwu kluczowym w niej terminom: hierarchii i pomocniczości.

Akurat takiego, jak u J. Regulskiego, pojmowania subsydiarności absolutnie uznać za trafne nie mogę, ale jego szerszej krytyki tutaj nie podejmuję. Samą koncepcję odczytuję jako szczególnie skrajny wyraz, z jednej strony nieufności wobec państwa, państwowej władzy i władzy w ogóle, a z drugiej, skądinąd w wydaniu osoby tak bardzo zaangażowanej w rekonstrukcję polskiej terytorialnej samorządności zrozumiałego, nawet sympatycznego, ale jednak bezkrytycznego zauroczenia terytorialną samorządnością. A ona przecież nie jest wolna od słabości poszczególnych ludzi, orientacji całych zbiorowości, dysfunkcjonalności przyjmowanych organizacyjnych rozwiązań i ograniczeń budowanych, jako intencjonalnie demokratyczne, systemów politycznych.

Wyeksponowanie w subsydiarności szczególnej pozycji jednostek ludzkich, poszczególnych indywiduów znajdowało i znajduje swe filozoficzne uzasadnienie $\mathrm{w}$ chrześcijańskim personalizmie. Nie ma i nie może być dwóch identycznych jednostek ludzkich, każdą jest osobą, żadna nie jest sobą i personalizmie. W uznaniu, że „Człowiek jest osobą, to znaczy między innymi naturą zindywidualizowaną jednocześnie kimś innym i żadna, będąc w najbardziej pierwotnym znaczeniu sobą, nie może stać się kimś innym. Pomiędzy moim Ja i twoim Ja nie ma drabiny, jest przerwa"34. To szczególne usytuowanie, uprzywilejowujące pozycję jednostki ludzkiej w subsydiarności, uzasadnia wywodzenie z niej wszystkich praw i obowiązków społeczeństwa i państwa ${ }^{35}$. Ale też nie zdejmuje z jednostek ograniczeń i zależności wynikających z ich przynależności - w pełnionych przez nich organizacyjnych i społecznych rolach - do różnych organizacji, różnych społeczności, społeczeństwa i wreszcie państwa i tego co ponad państwem.

Sam zamysł ochrony jednostki przed bezpośrednią ingerencją w jej działania państwa i wszelkich ponadjednostkowych podmiotów znajdujemy u powoływanego już A. Touraine’a, gdy upodmiotowieniem nazywa „ochronę praw

33 Wskazuje na nią odkryta przez norweskiego zoologa Th. Schjelderup-Ebbe hierarchia dziobania.

34 J. Tischner, Z problematyki wychowania chrześcijańskiego..., s. 30.

35 E. Popławska, Wpływ zasady subsydiarności..., s. 139. 
każdego - praw, które są powszechne - przed wszelkimi formami ingerencji społecznej. Taki klasyczny słownik integracji, socjalizacji świadomości zbiorowej budzi we mnie silną nieufność, która narasta w miarę jak indywidualizm coraz częściej zmienia się w komunitaryzm..."36. Bo, jeśli żąda się ochrony kogoś lub czegoś przed kimś lub przed czymś to tym samym daje się do zrozumienia, że to coś czy ten ktoś może być zagrożeniem. Od społeczności większych i silniejszych żąda się i oczekuje ochrony mniejszych i słabszych, a od mniejszych i słabszych współpracy z większymi i silniejszymi. I, w domyśle, nawołuje się: nie ograniczajcie i nie przeszkadzajcie, lecz pomagajcie.

W o trzydzieści lat późniejszej od Quadragesimo anno encyklice Jana XXIII Mater et magistra odnośnie subsydiarności czytamy: „Władze państwowe mogą nakazywać tylko to, co, jak można przypuszczać, prowadzi do powszechnego użytku obywateli. Dbając więc o dobro całego kraju, władze państwowe powinny troszczyć się usilnie o równomierny w miarę możliwości rozwój rolnictwa, przemysłu i usług. Należy przy tym trzymać się zasady, że mieszkańcy terenów opóźnionych w rozwoju powinni sami czuć się głównymi twórcami postępu w dziedzinie gospodarczej, społecznej i kulturalnej (wszystkie - podkr. L. H.). Ci bowiem są godni miana obywateli, którzy sami wnoszą wkład w dzieło poprawy swego losu.

Trzeba, aby do równomiernej rozbudowy gospodarczej w skali krajowej przyczyniali się także w miarę możliwości właściciele kapitału i przedsiębiorstw. Dlatego też - w myśl zasady pomocniczości - władze państwowe powinny wspierać i pobudzać inicjatywę osób prywatnych, a to w ten sposób, że będą, jeśli się tylko okaże możliwe, pozwalać na wykonywanie zaplanowanych działań" ${ }^{\prime 37}$. To porządek społeczny, w którym mamy do czynienia z spiętrzeniem kolejnych nadbudowywanych nad sobą ładów.

Zwróćmy uwagę, że encyklika Mater et magistra zaleca państwu nie powstrzymywanie się od podejmowania działań, lecz podejmowanie takich działań, które samozaradność jednostek wyzwalają i pobudzają. Dostarcza więc ona uzasadnienia nie dla wyboru jednego, tylko ograniczającego państwo, kierunku rozwiązań, lecz także takiego aktywności państwa i w państwie poszerzania - w każdym razie na miarę potrzeby współistnienia rożnych rozwiązań i porządków - które do indywidualnej aktywności zachęcają. Daje się odnaleźć w niej - otwierający społeczną przestrzeń do (samo)organizowania

36 A. Touraine, Myśleć inaczej..., s. 21.

37 Jan XXIII, Mater et magistra, [w:] Społeczne nauczanie Kościoła, „Znak” 1982, nr 7-9 (332-334), s. 805-806. 
się - postulat wspierania inicjatyw osób prywatnych, w szczególności też właścicieli kapitału i przedsiębiorstw. A to znaczy, że wspierania także podmiotów zbiorowych spoza struktury organów i aparatu państwa - podmiotów z sektora drugiego lub trzeciego - bez przesądzania o ich organizacyjnej czy prawnej postaci.

Takie upodmiotowianie może się nie podobać jako odgórnie wspierane i pobudzane. Wszakże w subsydiarności jest i dla niego miejsce; zarówno dlatego że Rosanvallowska kontrdemokracja to w końcu też demokracja, jak i dlatego że trwanie i funkcjonowanie demokratycznych instytucji zawsze wymaga ich ochrony ze strony państwowych organów i państwowego aparatu. To funkcja, w spełnianiu której nic nie jest w stanie zastąpić prawa i praworządności. Klucz do niej spoczywa w ręku władzę sprawujących. I takie tego klucza ulokowanie to zarazem słabość demokracji, ale również stworzenie miejsca na zabezpieczające ją prawno instytucjonalnych gwarancji.

W subsydiarności, na różnych poziomach jej rozpatrywania, jest miejsce i na, przez jednych, wytykanie państwu etatystycznego rozpychania się, i na, przez innych, kojarzone z liberalizmem i wycofywaniem się z aktywności, oddawaniem pola indywidualnej pazernej aktywności najbardziej przedsiębiorczych - w teorii przedstawianej w nowatorskiej postaci New Public Management - zastępujących niewydolne państwo w jego dotychczasowych aktywnościach ${ }^{38}$. Każdej z tych orientacji można bronić odwołując się do subsydiarności. To, o co w niej chodzi ,jest doświadczenie życia jako takiego, tak by nasze realne przeżycia na płaszczyźnie czysto fizycznej wywoływały rezonans w głębi naszej najbardziej wewnętrznej istoty i rzeczywistości, byśmy naprawdę doznali upojenia faktem życia. Ostatecznie, o to właśnie chodzi w mitach i to właśnie owe klucze pomagają nam odnaleźć się w nas samych. (...) Mity są kluczami do duchowych możliwości ludzkiego życia"39. Wspólnie podzielane integrują ponad realnymi podziałami.

Podejście takie, jak mam nadzieję, chroni również przed zbyt łatwym przechodzeniem do porządku dziennego nad wielopostaciowością subsydiarności i traktowaniem różnych jej poszczególnych przypadków (typów) tak jakby były wobec siebie współmierne i można było całkiem nieskrępowanie przechodzić od jednej do któregokolwiek innej bez słów dodatkowego komentarza.

38 Por. T. Judt, Źle ma się kraj. Rozprawa o naszych współczesnych bolączkach, Wołowiec 2011, s. 134.

39 J. Campbell, Potęga mitu. Rozmowy Billa Moyersa z Josephem Campbellem, Kraków 2013, s. 23. 
Takie - metodologicznie mało staranne - podejście odnajduję - to przykład jeden z wielu możliwych do przywołania - u A. Wyki gdy pisze: „Najkrócej, z moim elementem interpretacji, który przenoszę z Europy i świata, zasada pomocniczości oznacza, że jeśli administracja publiczna może jakieś zadanie wykonać zlecając je organizacjom pozarządowym, albo niższym szczeblom administracji, to musi to zrobić. I teraz są tu dwa elementy. Po pierwsze jest ten kierunek, powiedzmy, że jeżeli - w ramach administracji - rząd może przenieść na poziom województwa, bądź na poziom samorządu, to należy ten kierunek decentralizacji przyjąć. (...) I jest drugi kierunek, bardziej generalny, że jeżeli w ogóle administracja rządowa czy samorządowa, może coś zlecić organizacjom pozarządowym, to musi zlecać organizacjom pozarządowym"40.

Jednostronnie akcentujący jednostkowe prawo do chodzenia własnymi ścieżkami zdają się nie doceniać tego, że nie ma możliwości jego realnego zagwarantowania poszczególnym jednostkom takimi ścieżkami chodzącym bez przynajmniej ochrony wolności negatywnej tych jednostek, ochrony ich „wolności od". Takie jej zagwarantowanie wydaje się możliwe tylko z zewnątrz, $\mathrm{z}$ zewnątrz w tym mianowicie znaczeniu, że poprzez działania podejmowane przez podmioty ponadjednostkowe. Najważniejszy z tych podmiotów - dotyczy to przynajmniej społeczeństw sprzed fazy globalizacji - to, ulokowane na przeciwnym krańcu w stosunku do jednostki, państwo. Jeśli tak jest to nie ma subsydiarności bez państwa, bez spełnianych przez niego funkcji i korzystania z właściwych mu narzędzi ich sprawowania. Nie ma subsydiarności bez rozpatrywania wzajemnych relacji mniejszych i większych, słabszych i silniejszych podmiotów. Nie ma jej w szczególności bez pojawienia się między podmiotami takimi jako osoby fizyczne i państwo podmiotów - społeczności, stowarzyszeń itp. - będących tak czy inaczej zorganizowanymi zespołami ludzi. Przez analogię do pozycji poszczególnych fizycznych osób, wsparte przyznaniem im podmiotowości prawnej, konstruowane w postaci zorganizowanych zespołów ludzkich jednostek.

Subsydiarność w społeczeństwie politycznie zorganizowanym to żądanie - jak to się często mało refleksyjnie powtarza nawet w poważnej literaturze przedmiotu - możliwie najdalej idącego zbliżenia - co zdaje się być równoznaczne z przekazaniem - zadań czy władzy do jednostki, obywatela,

40 A. Wyka, Wokót zasady pomocniczości w Polsce, [w:] A. Gawkowska, P. Gliński, A. Kościański (red.), Teorie wspólnotowe. Praktyka społeczna. Obywatelskość, polityka, lokalność, Warszawa 2005, s. 166-167. 
w ostateczności głównie wspólnotowo, a nie społecznościowo ${ }^{41}$ postrzeganych indywidualnego człowieka, gminy czy jakiegokolwiek społecznego obiektu w danym układzie odniesienia uważanego za najmniejszy i najsłabszy. Problem w tym, że różne, nawet bardzo, bywa to, co w danym układzie odniesienia jest uważane za najmniejsze i najsłabsze. Ale także - ma się rozumieć, że nie w przypadku osób fizycznych - nie jest oczywiste czy podtrzymywania trwania najmniejszych i najsłabszych warto bronić, czy da się racjonalnie i społecznie usprawiedliwić. Czy w Polsce np. zwiększenie liczby gmin z około 2500 do 5000, a może nawet 10000 byłoby krokiem w kierunku pełniejszej implementacji subsydiarności? Czy byłyby nim podział obecnego województwa mazowieckiego na dwa i utworzenie województwa środkowopomorskiego?

A gdy już zdecydujemy się czyjej samodzielności bronić, stajemy przed decyzją jak bronić. Pamiętania, że równość wilków i owiec w korzystaniu z wolności to pewność pożarcia drugich przez pierwszych. „Wszelkie współżycie ludzi, jeśli chcemy, aby było dobrze zorganizowane i rozwijało się pomyślnie, musi opierać się na podstawowej zasadzie, że każdy człowiek jest osobą, to znaczy istotą obdarzoną rozumem i wolną wolą, wskutek czego ma prawa i obowiązki wypływające bezpośrednio i równocześnie z własnej jego natury. A ponieważ są one powszechne i nienaruszalne, dlatego nie można się ich w żaden sposób wyrzec"42.

Następujące zmiany cywilizacyjne stopniowo upodobniające świat do globalnej wioski zwiększają przestrzeń, w ramach której owe pojedyncze atomy poruszają się. Bez względu na to, jakie to są te atomy i w jak rozległej przestrzeni ma miejsce ich ruch zawsze są elementem realnego świata społecznego, w najprostszej postaci tworzonego przez zbiorowość zatomizowanych indywiduów w swych zachowaniach niebaczących na zachowania innych jednostek, tworzących statystyczny zbiór ogółu ludzkich jednostek bez względu na stan ich świadomości ${ }^{43}$. W terminologii cybernetyki zbiór taki byłby opisywany jako układ niespójny, addytywny, czyli taki, w którym całość (właściwości całości) jest (są) sumą jego części (właściwości poszczególnych części) ${ }^{44}$. Tymczasem

41 Na czym to rozróżnienie polega piszemy w: A. Habuda, L. Habuda, Nie wspólnota, lecz społeczność. W kwestii podmiotu terytorialnej samorządności, [w:] A.W. Jabłoński, Z.M. Nowak (red.), Demokracja - społeczeństwo - globalizacja, Opole 2005.

42 Jan XXIII, Pacem in terris, [w:] Spoleczne nauczanie Kościoła, „Znak” 1982, nr 7-9 (332-334), s. 832.

43 J. Szczepański, Elementarne pojęcia socjologii, Warszawa 1972, s. 243.

44 J.W. Gościński, Projektowanie systemów zarządzania, Warszawa 1971, s. 14-15. 
to nie wszystko. W życiu mamy do czynienia jeszcze z czymś nadto - i chyba bardzo dobrze, że tak jest - a mianowicie ze współdziałaniem poszczególnych części, a więc z układami przynajmniej w pewnym stopniu spójnymi i w konsekwencji holistycznymi. O takie współdziałanie łatwiej i jego efekty są bardziej satysfakcjonujące gdy współdziałających łączą wspólne idee.

Dla jednych życie wartościowe nie może być życiem wymuszonym, narzucanym jednostkom, musi być życiem samokierowanym, prowadzonym autonomicznie. Jest życiem poszczególnych działających jednostek, przynajmniej w jakimś zakresie prowadzonym bez względu na warunki otoczenia, w których działania te jednostki podejmują. Jest więc życiem - jakby, ale i tylko jakby - od zbiorowości niezależnym. Ale, jako przynajmniej fizycznie mającym miejsce w zbiorowości, nie tylko zabiegającym o zabezpieczenie sobie pewnej sfery odrębności i odgraniczenia od innych, ale i w zbiorowość wkomponowującym się. I wszystko to - mimo że demokracja oczekuje równości - z zachowaniem towarzyszących wolności po trosze nierówności, ale przede wszystkim zróżnicowania form uczestnictwa. Zróżnicowania według indywidualnych oczekiwań, łącznie z taką jego skrajną postacią jak - na to zdaje się być miejsce w subsydiarności - w ogóle wyłączenie się ze zbiorowości. Jak długo takie wyłączenie takiej wyłączonej jednostce służyłoby?

Tę samą ideę dowartościowania jednostki odnajdujemy u B. Constanta, gdy na około 120 lat przed ukazaniem się Quadragesimo anno pisał: ,Jednostki powinny cieszyć się całkowitą wolnością działania, dopóki jest ono nieszkodliwe lub obojętne. Jeśli, w szczególnych okolicznościach, działanie samo w sobie obojętne - na przykład noszenie stroju będącego znakiem rozpoznawczym - może zagrozić porządkowi publicznemu, społeczeństwo ma prawo tego zakazać" ${ }^{45}$. Wyprzedzająco zauważmy, że taki właśnie, konstrukcyjnie niekonsekwentny jest współczesny liberalizm; „to, kim jesteśmy, jak i co wybieramy, nie zależy tylko od nas, nie jest kwestią indywidualnego wyboru, jak twierdzą liberałowie, ale zależy też od jakości rozmowy, do której wkraczamy, w której bierzemy udział"46. Przez idących śladami tej niekonsekwencji zbiory fizycznych osób uzupełniane są o podmioty będące zorganizowanymi zespołami ludzkimi i traktowane na podobieństwo osób fizycznych. Oczywiście tylko

45 B. Constant, Zasady polityki mające zastosowanie do wszystkich rzadów, Warszawa 2008, s. 119.

46 P. Śpiewak, Poszukiwanie wspólnot, [w:] P. Śpiewak (red.), Komunitarianie. Wybór tekstów, Warszawa 2006, s. 11. 
do pewnego stopnia. To rozszerzenie grona podmiotów wyjściowego zbioru. Rozszerzenie wprowadzające w sferę obywatelskiego społeczeństwa.

Takie rozszerzenie zbioru jednostkowych działających podmiotów nasuwa skojarzenia z konstrukcją, wprowadzoną w XIII wieku do obrotu prawnego przez późniejszego papieża Innocentego III fikcyjnego bytu prawniczego, kategorii osoby prawnej ${ }^{47}$. To zabieg metodologiczny, narzędzie upraszczające i porządkujące opis i analizę realnej społecznej praktyki w konwencji przywołanych społecznych ładów i poprzez ich formalne upodmiotowienie uchwycenie ich związku z subsydiarnością, a w niej z rozróżnieniem podmiotów mniejszych i niższych oraz większych i wyższych.

Z kolei modyfikacja druga to potraktowanie praktykowanego przez tworzące zbiór jednostki „chodzenia własnymi ścieżkami” nie jako stanu atrofii, kompletnego bezładu, lecz ładu - pozostawiającego miejsce dla własnej podmiotowości tak zachowujących się - w porównaniu z innymi najmniej uporządkowanego, tylko wyjątkowo, a jeśli tak to tylko przez przypadek, prowadzącego do pojawienia się organizacyjnego (synergetycznego) efektu. Zbiorowość chodzących własnymi ścieżkami indywidualistów to istnienie obok siebie, to polifonia, w przypadku kolizji tak poruszających się mogąca przechodzić w kakofonię. Nawiązując do E. Durkheima można by powiedzieć, iż jest to ta część jednostkowej świadomości, która ,reprezentuje wyłącznie naszą świadomość indywidualną i tę tworzy" ${ }^{\text {"48. }}$

Taki ład, potraktowany jako bezład, w ogóle nie znalazł się w S. Ossowskiego typologii społecznych ładów. Natomiast przez J. Karpińskiego, chyba zbyt pochopnie, został opisany i zarazem jednoznacznie negatywnie oceniony jako stan dezorganizacji, izolacji społecznej i anomii. Ma on niewątpliwie swoje słabe strony, ale ma też strony mocne. Ale przede wszystkim, niezależnie od tego jak go oceniamy, jest socjobiologicznym faktem. I dzieci i zwierzęta przestrzegają zachowania odległości dzielących ich od innych, „otaczają się niewidzialnymi przestrzennymi «kokonami», które zdecydowanie uznają za swoją wyłączność"49. Nadmierne stłoczenie zabija mimo obfitości pokarmu, zabija z przyczyn natury psychospołecznej, i dotyczy to także świata zwierząt ${ }^{50}$.

47 J.S. Coleman, Racjonalna rekonstrukcja społeczeństwa, „Studia Socjologiczne” 1992, nr 1, s. 9.

48 E. Durkheim, O podziale pracy społecznej, Warszawa 1999, s. 136.

49 R. Pipes, Wtasność a wolnośćc, Warszawa 2000, s. 121.

so E.T. Hall, Ukryty wymiar, Warszawa 1976, s. 48-51 
Nie powiedzielibyśmy też, iż jest zjawiskiem kurczącym się, bądź tracącym na znaczeniu. Powrót do natury, jeśli nawet miałby być przede wszystkim hasłem, jest hasłem mającym szansę spotykać się z większym niż kiedykolwiek w przeszłości pozytywnym odzewem i zrozumieniem. Takie odwoływanie się nawet wówczas gdy tylko pozorowane też nie jest bez znaczenia. Operacja jednakowego potraktowania poszczególnych fizycznych osób i działających na podobieństwo osób fizycznych zorganizowanych podmiotów zbiorowych - przybierających prawniczą konstrukcję osób prawnych - wydaje się poznawczo nośna, a jej podstawowa zaleta to możliwość wytłumaczenia i usprawiedliwienia (tutaj oczywiście tylko czasowego) braku zainteresowania wewnętrzną strukturą takich zbiorowych podmiotów.

Formalnych podstaw dla takiego metodologicznego zabiegu dostarczają art. 12 Konstytucji RP (Rzeczpospolita Polska zapewnia wolność tworzenia i działania związków zawodowych, organizacji społeczno-zawodowych rolników, stowarzyszeń, ruchów obywatelskich, innych dobrowolnych zrzeszeń oraz fundacji) oraz rozliczne ustawy zwykłe, w tym mające za przedmiot regulacji spółki prawa handlowego, przedsiębiorstwa państwowe, stowarzyszenia, fundacje, partie polityczne, organizacje pożytku publicznego etc. Poprzez analogię usytuowania podmiotu zbiorowego do usytuowania powołującej się na swe naturalne prawa osoby ludzkiej może być i bywa wykorzystywana jako ideologiczny argument uzasadniający liberalizm w różnych jego postaciach i sferach, przede wszystkim jednak dla obrony wolnego, konkurencyjnego rynku w gospodarce. Inna sprawa, na ile - w całej swej rozciągłości - jest to obrona przekonująca. Mam co do tego poważne wątpliwości.

W społeczeństwie wszystkie je, po części idąc śladami papieskich encyklik, po części zaś rozróżnień przyjętych przez S. Ossowskiego, konstruujemy przyjmując dla relacji, w jakich pozostają ze sobą, poszczególne tworzące dane zbiorowości podmioty - osoby fizyczne i traktowane niczym osoby fizyczne organizacje zbiorowego współdziałania - pięciorakie typy poziomów stanowiących odniesienia dla subsydiarności. A te poziomy (odniesienia) to dwa skrajne: 1. poszczególne osoby, ich jednostkowy indywidualizm, wynikający ze społecznego podziału pracy, zróżnicowania ról pełnionych przez poszczególne jednostki, w ramach nie koordynowanego z zewnątrz mniej lub dalej sięgającego współdziałania w systemie stosunków policentrycznych oraz 2. państwo, jego organy i urzędy, od których oczekuje się wypełniania co najmniej luk, które pozostawiły po sobie, lub niespójności, których stały się 
przyczyną dwa wcześniejsze wyróżnione przez S. Ossowskiego łady, a nadto przez swą aktywność zapewniające wypełnianie nowych funkcji, które wynikają $\mathrm{z}$ potrzeby skoordynowania i zintegrowania $\mathrm{w}$ niezbędnym zakresie i zapewnienia współdziałania i uzupełniania się w społeczeństwie różnych w tym i nie wyróżnionych tutaj - typów ładu. Łady ulokowane między dwoma opisywanymi tutaj jako skrajne, to takie, w których mamy do czynienia ze współdziałaniem podmiotów zbiorowych po części naturalnych (np. społeczności terytorialnych), po części celowo skonstruowanych, zorganizowanych i kierowanych, czyli policentryczne współdziałanie generalnie głównie monocentrycznie kierowanych organizacji, umożliwiające poszczególnym z tak współdziałających podmiotów osiągnięcie synergetycznego efektu.

Takie ujęcie, oczywiście z odpowiednimi modyfikacjami, daje się odnieść do rzeczywistości konstruowanej - w tym państwa, jego ustroju i struktury jego poszczególnych instytucji. I wykorzystania go (ujęcia) do - zgodnego z ideą subsydiarności - rozmieszczenia kompetencji w strukturze jego organów i aparatu. Ale to nic nowego. To problem centralizacji vs decentralizacji zarządzania, decyzji i kompetencji rozważany w teorii organizacji i zarządzania oraz nauce o administrowaniu (nauce administracji). Pisali na ten temat najznakomitsi ich przedstawiciele jak, w literaturze światowej choćby H. A. Simon ${ }^{51}$, a w polskiej J. Starościak ${ }^{52}$ i S. Kowalewski ${ }^{53}$.

Połączenie wszystkich tych rozważań pod hasłem subsydiarności ${ }^{54}$ ma tę podstawową zaletę, że wszystkie one pozwala skoncentrować na podmiotowości - niezależności i samodzielności w ramach rozpatrywanych układów odniesienia. Aby jednak coś więcej dowiedzieć się o sposobach tej podmiotowości zapewnienia i ochrony konieczne jest ,zejście” na niższe poziomy rozważań: praw i wolności człowieka, liberalizmu vs etatyzmu, ustroju politycznego etc. i bardziej szczegółowych dyscyplin naukowych jak np. teoria organizacji i zarządzania oraz nauka administracji (o administrowaniu).

51 H.A. Simon, Działanie administracji. Podejmowanie decyzji w organizacjach administracyjnych, Warszawa 1976.

52 J. Starościak, Zarys nauki administracji, Warszawa 1971.

53 S. Kowalewski, Nauka o administrowaniu...,

54 Klasycznym tego przypadkiem praca zbiorowa pod red. A. Pawłowskiej i S. Grabowskiej, Zasada pomocniczości. Wymiar europejski, narodowy, regionalny i lokalny, Rzeszów 2011. 


\section{Literatura}

1. Campbell J., Potega mitu. Rozmowy Billa Moyersa z Josephem Campbellem, Wydawnictwo Znak, Kraków 2013.

2. Coleman J.S., Racjonalna rekonstrukcja społeczeństwa, „Studia Socjologiczne” 1992, nr 1.

3. Constant B., Zasady polityki mające zastosowanie do wszystkich rządów, Fundacja Res Publica, Warszawa 2008.

4. Delsol Ch., Czym jest człowiek? Kurs antropologii dla niewtajemniczonych, Społeczny Instytut Wydawniczy Znak, Kraków 2011.

5. Durkheim E., O podziale pracy spolecznej, Wydawnictwo Naukowe PWN, Warszawa 1999.

6. Frysztacki K., Solidarność, [w:] M. Bogunia-Borowska (red.), Fundamenty dobrego spoteczeństwa. Wartości, Znak, Kraków 2015.

7. Habuda A., Habuda L., Nie wspólnota, lecz społeczność. W kwestii podmiotu terytorialnej samorządności, [w:] A.W. Jabłoński, Z.M. Nowak (red.), Demokracja-społeczeństwoglobalizacja, Wydawnictwa Wyższej Szkoły Zarządzania i Administracji w Opolu, Opole 2005.

8. Habuda L., Jednolitość kierowania w literaturze organizacji i zarzadzania, „Prakseologia” 1975, nr 1 .

9. Habuda L., Polska reforma terytorialnego samorządu. Osobisty ślad odciśnięty na niej przez jej trzech współautorów, „Atheneaum. Polskie Studia Politologiczne” 2015, nr 47.

10. Hall E.T., Ukryty wymiar, Państwowy Instytut Wydawniczy, Warszawa 1976.

11. Szczepański J., Elementarne pojęcia socjologii, PWN, Warszawa 1972.

12. Gościński J.W., Projektowanie systemów zarządzania, PWN, Warszawa 1971.

13. Jan XXIII, Mater et magistra, [w:] Społeczne nauczanie Kościoła, „Znak” 1982, nr 7-9 (332-334).

14. Jan XXIII, Pacem in terris, [w:] Społeczne nauczanie Kościoła, „Znak” 1982, nr 7-9 (332-334).

15. Jasińska-Kania A., Miłość, [w:] M. Bogunia-Borowska (red.), Fundamenty dobrego społeczeństwa. Wartości, Znak, Kraków 2015.

16. Judt T., Źle ma się kraj. Rozprawa o naszych wspólczesnych bolączkach, Wydawnictwo Czarne, Wołowiec 2011.

17. Kowalewski S., Nauka o administrowaniu, Książka i Wiedza, Warszawa 1976.

18. Kulesza M., Zasada subsydiarności jako klucz do reform ustroju administracyjnego państw Europy Środkowej i Wschodniej (na przykładzie Polski), [w:] D. Milczarek (red.), Subsydiarność, Centrum Europejskie Uniwersytetu Warszawskiego, Warszawa 1998.

19. Leon XIII, O kwestii robotniczej (Rerum novarum), [w:] Społeczne nauczanie Kościoła, „Znak” 1982, nr 332-334.

20. Millon-Delsol Ch., Zasada pomocniczości, Społeczny Instytut Wydawniczy, Kraków 1995.

21. Millon-Delsol Ch., Zasada subsydiarności-założenia, historia, problemy współczesne, [w:] D. Milczarek (red.), Subsydiarność, Centrum Europejskie Uniwersytetu Warszawskiego, Warszawa 1998.

22. Ossowska M., O dwóch rodzajach ocen, „Kwartalnik Filozoficzny” 1964, nr 2-4. 
23. Ossowski S., Koncepcje ładu społecznego i typy przewidywań, [w:] S. Ossowski, O osobliwościach nauk społecznych, Państwowe Wydawnictwo Naukowe, Warszawa 1962.

24. Pawłowskiej A., Grabowska S., Zasada pomocniczości. Wymiar europejski, narodowy, regionalny i lokalny, Wydawnictwo Uniwersytetu Rzeszowskiego, Rzeszów 2011.

25. Piasecki A., Pomocniczość samorządowego województwa. Teoria i praktyka, [w:] A. Pawłowska, S. Gawłowska (red.), Zasada pomocniczości. Wymiar europejski, narodowy, regionalny i lokalny, Wydawnictwo Uniwersytetu Rzeszowskiego, Rzeszów 2011.

26. Pipes R., Własność a wolność, Wydawnictwo Literackie Muza, Warszawa 2000.

27. Pius XI, Quadragesimo anno, [w:] Nauka społeczna Kościoła, „Znak” 1984, nr 7-9 (332-334).

28. Popławska E., Wpływ zasady subsydiarności na przemiany ustrojowe w Polsce, [w:] D. Milczarek (red.), Subsydiarność, Centrum Europejskie Uniwersytetu Warszawskiego, Warszawa 1998.

29. Regulski J., Samorzqdna Polska, Rosner i Wspólnicy, Warszawa 2005.

30. Rosanvallon P., Kontrdemokracja. Polityka $w$ dobie nieufności, Wydawnictwo Naukowe Dolnośląskiej Szkoły Wyższej, Wrocław 2011.

31. Simon H.A., Działanie administracji. Podejmowanie decyzji w organizacjach administracyjnych, Państwowe Wydawnictwo Naukowe, Warszawa 1976.

32. Społeczeństwo obywatelskie bez obywateli. Z prof. Andrzejem Sicińskim, socjologiem kultury o obrazie Polski w Europie, elitach i klikach politykierów rozmawia Mariusz Urbanek, „Odra” 2006, nr 1.

33. Starościak J., Zarys nauki administracji, Państwowe Wydawnictwo Naukowe, Warszawa 1971.

34. System Putina. Garri Kasparow w rozmowie z autorem ,, Tygodnika”, Jackiem Stawiskim, "Tygodnik Powszechny" z dn. 12.10.2012 r.

35. Śpiewak P., Poszukiwanie wspólnot, [w:] P. Śpiewak (red.), Komunitarianie. Wybór tekstów, Wydawnictwo Aletheia, Warszawa 2006.

36. Tischner J., Z problematyki wychowania chrześcijańskiego, [w:] J. Tischner, Świat ludzkiej nadziei, Społeczny Instytut Wydawniczy Znak, Kraków 1992.

37. Touraine A., Myśleć inaczej, Państwowy Instytut Wydawniczy, Warszawa 2011.

Ludwik Habuda

Państwowa Wyższa Szkoła Zawodowa im. Angelusa Silesiusa w Wałbrzychu 